\section{OPERATION STATISTICS OF THE GLASGOW ROYAL INFIRMARY.}

BY M. THOMAS, M.D., F.F.P.S. GLAS., SUPERINTENDENT TO THE INFIRMARY.

As the statistics of operations given by Sir James Simpson are oftener quoted than those of any other authority, it occurred to me, after finishing the paper which appeared in THE LANCET of July lst, to make an exact comparison, and on the same lines, of the operations performed here from 1868 to the present time. This is a continuation of the statistics of this hospital, as given by Sir James, of the previous eighteen years. The subjoined table shows the very satisfactory results.

The decrease in the fatality of the operations during the last thirteen years ranges from 16.8 to 4.6 per cent. There is an increase of 13 per cent. in only one set of amputationsviz., secondary for disease of the forearm.

The total number of cases for the thirteen years was 822 ; deaths, 212 ; or $25 \cdot 5$ in every 100 , against $39 \cdot 1$ as given by Sir James.

The total number of amputations for injury was 397 ; deaths, 126 ; or $31 \cdot 7$ per cent., against 43.6 per cent.

The total number of amputations for disease was 425 ; deaths, 86 ; or $20 \cdot 2$ per cent., against $33 \cdot 8$ per cent.

Results of the four amputations of the Thigh, Leg, and Forearm, in the Glasgow Royal INFirmary, in the Same Manner as grven by Sir James Simpson in his Paper on Hospitalism.

\begin{tabular}{|c|c|c|c|c|c|c|c|c|c|c|c|c|c|c|c|c|}
\hline \multirow{3}{*}{ Year. } & \multicolumn{8}{|c|}{ Primary. } & \multicolumn{8}{|c|}{ SECONDARY, FOR DISEASE. } \\
\hline & \multicolumn{2}{|c|}{ Thigh. } & \multicolumn{2}{|c|}{ Leg. } & \multicolumn{2}{|c|}{ Arm. } & \multicolumn{2}{|c|}{ Forearm. } & \multicolumn{2}{|c|}{ Thigh. } & \multicolumn{2}{|c|}{ Leg. } & \multicolumn{2}{|c|}{ Arm. } & \multicolumn{2}{|c|}{ Forearm. } \\
\hline & $\begin{array}{l}\text { No. of } \\
\text { cases. }\end{array}$ & Deaths. & $\begin{array}{l}\text { No. of } \\
\text { cases. }\end{array}$ & Deaths. & $\begin{array}{l}\text { No. of } \\
\text { cases. }\end{array}$ & Deaths. & $\begin{array}{l}\text { No. of } \\
\text { cases. }\end{array}$ & Deaths. & $\begin{array}{l}\text { No. of } \\
\text { cases. }\end{array}$ & Deaths. & $\begin{array}{l}\text { No. of } \\
\text { cases. }\end{array}$ & Deaths. & $\begin{array}{l}\text { No. of } \\
\text { cases. }\end{array}$ & Deaths. & $\begin{array}{l}\text { No. of } \\
\text { cases. }\end{array}$ & Deaths. \\
\hline 1869 & 7 & 3 & 7 & 4 & 8 & 3 & $\mathbf{5}$ & 1 & 18 & 5 & 6 & 3 & 3 & 0 & 2 & 0 \\
\hline 1870 & 5 & 1 & 13 & 5 & 8 & 2 & 6 & 0 & 19 & 3 & 12 & 2 & 4 & 0 & 4 & o \\
\hline 1871 & 9 & 4 & 6 & 5 & 13 & 1 & 10 & 2 & 3 & 0 & 2 & 1 & 8 & 1 & 1 & o \\
\hline 1872 & 11 & 3 & 12 & 5 & 7 & 2 & 5 & 0 & 31 & 9 & 9 & 1 & 5 & 2 & 7 & 2 \\
\hline 1873 & 21 & 6 & 7 & 2 & 4 & 0 & 0 & 0 & 16 & 3 & $\mathbf{9}$ & 0 & 6 & 1 & 3 & 0 \\
\hline 1874 & 15 & 9 & 8 & 5 & 14 & 5 & 4 & 1 & 31 & 12 & 11 & $\mathbf{3}$ & 9 & 3 & 4 & 2 \\
\hline 1875 & 12 & 9 & 6 & 2 & 13 & 4 & 4 & 0 & 23 & 5 & 5 & 0 & 4 & 0 & 6 & 2 \\
\hline 1876 & 9 & 3 & 7 & 3 & 6 & 0 & 2 & 0 & 22 & 5 & 3 & 1 & $\mathbf{3}$ & 0 & 1 & $\overline{\mathbf{0}}$ \\
\hline 1877 & 9 & 6 & 9 & 3 & 3 & 1 & 3 & 0 & 16 & 2 & 8 & 1 & 6 & $\mathbf{0}$ & 1 & o \\
\hline 1878 & 9 & 1 & 8 & 1 & 7 & 2 & 5 & 1 & 19 & 3 & 6 & 1 & 2 & $\mathbf{0}$ & 2 & $\mathbf{I}$ \\
\hline 1879 & 8 & 4 & 4 & 3 & 8 & 1 & 1 & 0 & 16 & 2 & 2 & $\overline{0}$ & 2 & 1 & 4 & 0 \\
\hline 1880 & 9 & 5 & 4 & 0 & 7 & 0 & 6 & 0 & 20 & 1 & 4 & 1 & $\overline{1}$ & 0 & 1 & o \\
\hline \multirow[t]{4}{*}{1881} & 10 & $\mathbf{5}$ & 7 & 1 & 12 & 2 & 4 & 0 & 12 & 4 & 7 & 1 & 4 & 2 & 2 & 0 \\
\hline & 134 & 59 & 98 & 39 & 110 & 23 & 55 & 5 & 246 & 54 & 841 & 15 & 57 & 10 & 38 & 7 \\
\hline & \multicolumn{2}{|c|}{$44 \cdot 0$} & \multicolumn{2}{|c|}{$39 \cdot 8$} & \multicolumn{2}{|c|}{$20 \cdot 8$} & \multicolumn{2}{|c|}{$9 \cdot 0$} & \multicolumn{2}{|c|}{$21 \cdot 9$} & \multicolumn{2}{|c|}{$17 \cdot 6$} & \multicolumn{2}{|c|}{$17 \cdot 5$} & \multicolumn{2}{|c|}{$18 \cdot 4^{*}$} \\
\hline & \multicolumn{2}{|c|}{$60 \cdot 0$} & \multicolumn{2}{|c|}{$53 \cdot 7$} & \multicolumn{2}{|c|}{$37^{\circ} 6$} & \multicolumn{2}{|c|}{$13 \cdot 6$} & \multicolumn{2}{|c|}{$38 \cdot 4$} & \multicolumn{2}{|c|}{$32 \cdot 9$} & \multicolumn{2}{|c|}{$26^{\circ} 0$} & \multicolumn{2}{|c|}{$5 \cdot 2+$} \\
\hline
\end{tabular}

f Mortality per cent. of the previous eighteen years, as given by Sir James Simpson in his paper on Hospitalism.

Mortality of the Four Major Amputations, combining together Operations for Injuries and Operations for Disease.

\section{Per cent.}

Thigh cases, 380 ; deaths, 113 ; mort., $29 \cdot 7$, agst. $46 \cdot 2$

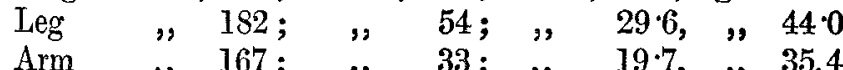

Forearm ", $93 ; \quad$ " 12 ; ", $12 \cdot 9, \quad, 11 \cdot 7$

In addition to the decreased mortality, which I attribute chiefly to the use of antiseptics, another noticeable feature in these statistics is the increase in the number of operations. In eighteen years the number was 661 ; for the last thirteen years the number was 822 ; an increase of 19 per cent. It is to be hoped the mortality will continue to decrease, but I fear it will never reach the low percentage of country operations, as cases of the worst description are occasionally sent to us from some of the very districts mentioned by Sir James as places where success had been achieved, such as Motherwell, Airdrie, \&c. It is impossible that cases coming so far can have the same chance as those treated at home; but there can be no doubt it is the discomfort of their homes which forces the country practitioner to send them into the infirmary. Small hospitals in such localities would be an immense boon to the poor sufferers, and their erection is only a question of time.

\section{MODERN STUDY OF MICRO-ORGANISMS,} AND ITS INFLUENCE ON MEDICAL THOUGHT. ${ }^{1}$

By SOLOMON CHARLES SMITH, M.D., SURGEON TO TIEE HALIFAX INRIRMARY.

I WISH to draw attention to the position to which recent researches on bacteria have brought us in regard to the interesting question of the relation between micro-organisms and di:ease, partly because the subject is a most thoughtproducing one, partly because it is one in the investigation of which great strides have lately been made, and especially since in its elucidation we have now arrived at a point from

1 Read before the Yorkshire Branch of the British Medical Associa. tion beld at Leeds, July 26th, 1882. which research may advance along two separate lines, each useful when checked by the other, but liable to lead to error if prosecuted alone, and because there is great temptation to us all, in consequence of the brilliancy of the results lately obtained, to rush into the microscopic line of inquiry as to the nature of the germs of disease, to the exclusion of that other line of research, which I think is so important, as to the nature of those conditions which make man's body a fit nidus for the hatching of those germs, and the development of the diseases to which they are related. All our knowledge on this subject is new : the discovery of the yeast plant only took place in 1835, the trichophyton of lingworm ten years later, and the relation between living germs and suppuration only fifteen years ago ; but the demonstration of the spirillum of relapsing fever, the bacilli of antbrax, of enteric fever, and now of tubercle, are things of the very present. And it seems probable that the widering of the circle of diseases which must be considered infect veresulting from this new knowledge will lead to some modification of 